\title{
Research
}

\section{Growth, Collapse, and Reorganization of the Annapurna Conservation Area, Nepal: an Analysis of Institutional Resilience}

\author{
$\underline{\text { Nabin Baral }}^{1}, \underline{\text { Marc J. Stern }}^{1}$, and $\underline{\text { Joel T. Heinen }}^{2}$
}

\begin{abstract}
Community-based conservation institutions can be conceptualized as complex adaptive systems that pass through a cycle of growth, maturation, collapse, and reorganization. We test the applicability of this four-phase adaptive cycle in the institutional context of the Annapurna Conservation Area (ACA), Nepal. We use the adaptive cycle to assess changes in structures and processes and to explore the past, present, and possible future trends in ACA. We focus on the crisis brought about by the Maoist insurgency and changes that took place in ACA during and after this period. Our analysis suggests that the conservation institution has passed through one and a half forms of the adaptive cycle in five major historical periods in the Annapurna region since 1960. It also appears to have been resilient to the insurgency because the system maintained its identity throughout, avoided alternative undesirable states, and entered into the reorganization phase following collapse. All forms of capital and institutional performance decreased to some extent during collapse, but flexible nested governance structures, including the devolution of responsibility to local entities, the maintenance of capital stocks, the retention of institutional memory, and the perceptions of institutional legitimacy among constituencies, facilitated reorganization. The institutional system is reorganizing along the original regime, but it has also developed an alternative pathway that will transform it in the near term. We evaluate the usefulness, strengths, and weaknesses of the adaptive cycle analogy in this application.
\end{abstract}

Key Words: Annapurna; adaptive cycle; community-based conservation; protected areas management; resilience; social-ecological system; sustainability science

\section{INTRODUCTION}

Community-based conservation institutions are representative of social-ecological systems in which humans are an integral part of ecosystems and emphasis is given to a systems view of nature (Berkes and Folke 1998, Berkes 2004). These institutions can be conceptualized as complex adaptive systems because they are composed of interacting agents, have emergent properties resulting from agent interactions, can self-organize to find the best fit with the environment, and have processes that tend to be nonlinear and unpredictable (Levin 1999, Gunderson and Holling 2002). Forward-looking and reflexive behaviors of human agents add complexity to these systems.

These characteristics have implications for the management and sustainability of communitybased conservation. Over the past three decades, some community-based conservation initiatives have achieved a reasonable amount of success while others have not (West and Brechin 1991, Wells et al. 1992, Western et al. 1994, Ghimire and Pimbert 1997, Terborgh et al. 2002, McShane and Wells 2004). This phenomenon cannot be explained by simple rules of cause and effect because ecological processes are interlinked with social processes (Berkes and Folke 1998). This requires complex systems thinking. A critical question with regard to successful models is "How do they adapt to change?" This warrants the assessment of their resilience: the capacity to endure disturbances and reorganize. Building resilience within communitybased conservation institutions can suppress negative feedback between ecological and social systems (World Resources Institute 2008), and with increased resilience, institutions may be better prepared to accommodate environmental and social disruption. 
Holling's (1987) adaptive cycle framework hypothesizes that resilience of an ecosystem changes as its structures and processes follow a fourphase cycle of exploitation, conservation, release, and reorganization (Figure 1). The exploitation (r) phase is dominated by fast growing species that are adapted to dealing with stress and which capitalize on disturbed environments. As structures and connections increase within the system, more energy and resources are required to maintain them. Thus, in the conservation $(\mathrm{K})$ phase, a slow accumulation and storage of materials and energy (or capital) occurs. The $\mathrm{r}$ and $\mathrm{K}$ phases constitute the "fore loop", which is slow, predictable, and analogous to ecological succession. Disturbances trigger the release $(\Omega)$ phase in which bound capital is suddenly released and accumulated structures collapse. Novelty can lead to the reorganization $(\alpha)$ phase in which released materials are mobilized to start another exploitation phase in a new cycle. The $\Omega$ and $\alpha$ phases together are known as the "back loop", which is fast, unpredictable, and critical to determining the system's fate.

The adaptive cycle has three dimensions that capture dynamic changes in ecosystems: capital, connectedness, and resilience (Gunderson and Holling 2002). Capital is the amount of available resources that determines the range of options possible for change. Connectedness refers to the degree of control of the system exerted by a system's internal elements and their interactions with each other. Too much connectedness can lead to rigidity and reduce the flexibility of the system to accommodate disturbance. Resilience is a measure of the system's vulnerability to disturbance. During the $r$ phase, pioneer species grow and accumulate capital. Because of accumulated capital and the system's high flexibility, resilience remains high. In the $\mathrm{K}$ phase, capital is bound within existing structures, preventing other competitors from utilizing it. System connectedness increases causing the system to become increasingly rigid. As a result, resilience decreases. Bound capital becomes increasingly fragile until released by disturbance. The system enters into the $\Omega$ phase and tight organization is lost, as is capital. The system becomes less rigid and its resilience starts to expand. In the $\alpha$ phase, the processes within the system minimize capital loss and reorganize remaining capitals to make them available for the next phase of exploitation. There is a higher degree of flexibility for the system to change and adapt, so resilience is high. In this phase, innovation and restructuring take place. During the slow sequence of the fore loop, connectedness and stability increase and capital is slowly accumulated. Accumulated capital tends to deplete during the release and reorganization phases. Any stock retained in the back loop influences the system's resilience.

The adaptive cycle dynamics at any scale are influenced by the dynamics of linked systems at both finer and broader scales. Panarchy refers to the hierarchical structure in which these various systems are interlinked (Gunderson and Holling 2002). In panarchy, each level operates at its own pace, protected from above by slower, larger cycles storing memory but invigorated from below by faster, smaller cycles of innovation. Panarchy theory explains the evolving nature of complex adaptive systems as a nested set of adaptive cycles (Holling 2001). Thus, the sustainability of any system is determined by the functioning of adaptive cycles at each level and the communication between them.

The adaptive cycle has been used to study retention of ecological knowledge among local communities (Madzwamuse and Fabricius 2004), management of rangeland ecosystems (Abel et al. 2006), and forest governance in public lands (Beier et al. 2009). We attempt to integrate this ecological concept into community-based conservation to study its resilience. To our knowledge, there is no study in which the adaptive cycle framework has been applied to the institutional context of communitybased protected area management. We apply this concept to Annapurna Conservation Area (ACA), Nepal. ACA is an IUCN Category VI protected area managed by the Annapurna Conservation Area Project (ACAP) and local Conservation Area Management Committees (CAMCs). We define institution as the set of mechanisms and structures guiding the governance of ACA, where governance refers to the arrangements and processes that guide decision-making (Ostrom 1990). The concept of institution is explored at the scale of a protected area in which formal rules, regulations, nongovernmental organizations (NGOs), and community-based organizations interact to influence the management of ACA. We define institutional resilience as the capacity of the conservation institution to remain functional, maintain its identity, and adapt and reorganize during and following the decade-long Maoist insurgency in Nepal (Carpenter et al. 2001, 
Fig. 1. The two dimensional representation of the adaptive cycle. The Y-axis reflects the changes in the amount of accumulated capital stored in dominant keystone variables, while the $\mathrm{X}$ - axis depicts the degree of connectedness among variables. Following collapse, the system can reorganize and repeat the previous cycle (following a white path) or transform into another system configuration (following a black path). (Source: Adapted from Holling 1987 )

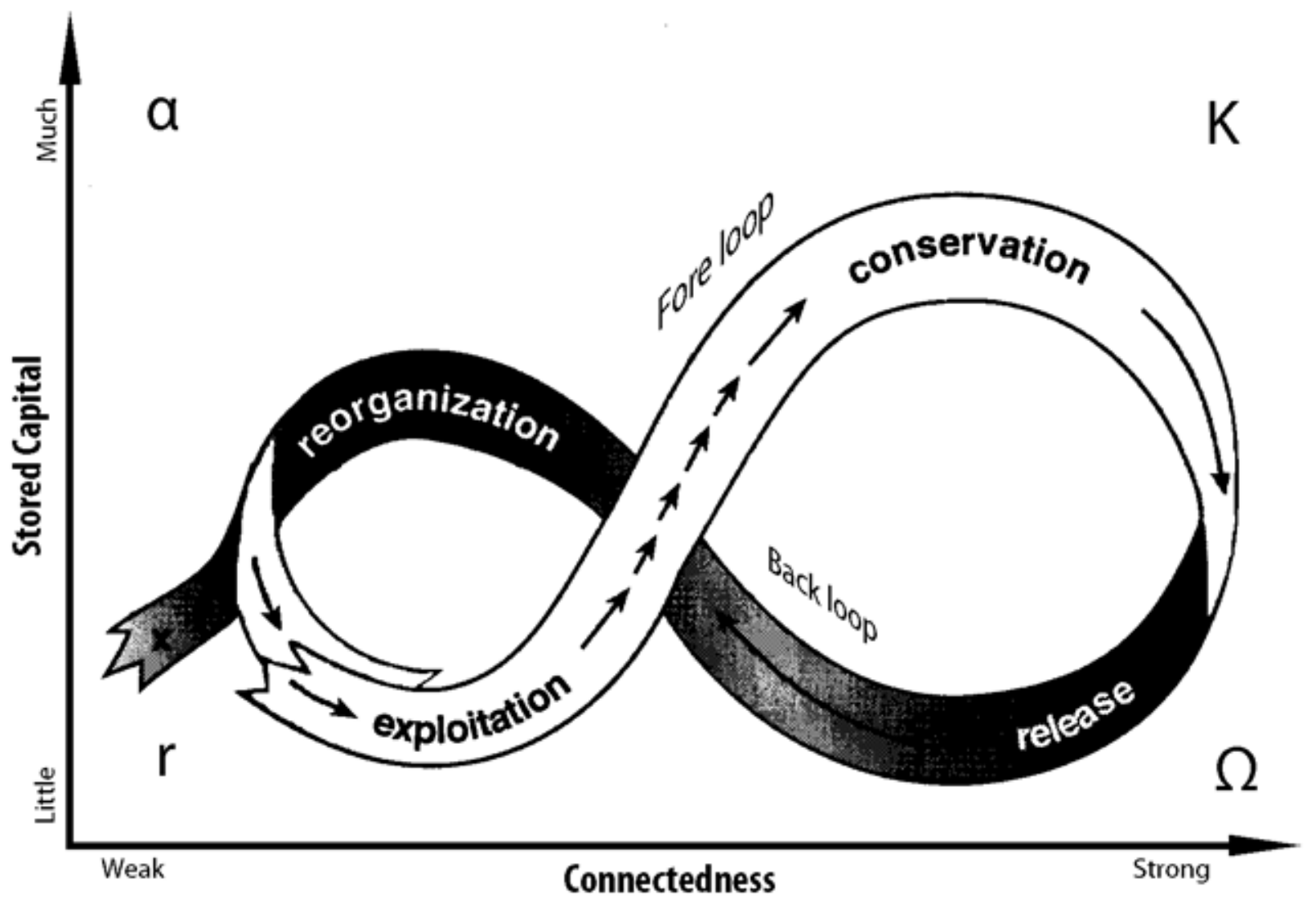

Folke and Gunderson 2006). Our aim is to assess the usefulness of the adaptive cycle framework in understanding the growth, collapse, and reorganization of ACA since its inception. We describe historical events leading to the establishment of ACA, how it is governed, what contributed to its success, what made it vulnerable to disturbance, how it responded, and under which development paths it is reorganizing. By doing so, we also address the resilience of the conservation institution.

\section{STUDY AREA}

The Annapurna Himalayas includes ecosystems ranging from subtropical forests to trans-Himalayan cold deserts. In 1992, the region was legally gazetted as a Conservation Area of $7629 \mathrm{~km}^{2}$ (Heinen and Shrestha 2006). A pioneer experiment of integrating natural and social systems into Nepali protected areas management has been carried out in the Conservation Area since its establishment. In the past, low human population densities belonging to various ethnic groups engaged primarily in subsistence agriculture, resource extraction, and 
semi-transhumance livestock herding. At present, about 120,000 people belonging to various ethnic groups of Tibetan and Indo-European origin reside inside the Conservation Area. Major economic activities include subsistence agriculture, recruitment in security forces (mainly the Indian and British Army), small businesses, seasonal migration to cities, and tourism. ACA is a representative example of a social-ecological system because local extractive uses of resources are an integral part of the area's ecology.

Nepal's National Parks and Wildlife Conservation Act defines conservation areas as those reserves managed for integrated conservation and development, in which local communities participate in management, some extractive uses are permitted, and tourism is promoted. The primary goal of ACA is to foster conservation through rural development (Heinen and Mehta 1999). At the local level, communities organized into 56 CAMCs manage ACA. All CAMCs are similar in that they operate under the same legal framework, work to fulfill legitimate local demands for resources, and integrate traditional resource management into protected area management. They differ in ethnic composition, socio-economic indicators, and ecological settings.

\section{RESEARCH APPROACH AND METHODS}

We drew upon a series of cross-sectional studies and integrated both insider and outsider perspectives into this research. The first author worked for ACAP in 2001 and 2002 in the capacity of Conservation Officer, and participated in policy and management designs. Since then he has closely followed developments in the area. The first author undertook field reasearch for this study for one month in 2004, two months in 2006, four months in 2007, and four months in 2008. This roughly spanned three important time periods in the area: pre-Maoist insurgency, during the insurgency, and post-insurgency.

During the summer of 2007, we conducted semistructured interviews with 190 executive members of 30 representative CAMCs and with 13 ACAP officials. These interviews averaged 35 minutes. We also solicited villager perceptions of the trustworthiness of CAMC members and of the legitimacy of CAMCs by quota sampling 207 households within four management units. These face-to-face surveys typically lasted less than 15 minutes each. In the fall of 2008 , we interviewed 661 households in six CAMC management units selected by stratified random sampling. We primarily solicited local villagers' perceptions about the institutional resilience, legitimacy, and costs and benefits associated with CAMCs. The interviews lasted less than 20 minutes each. As a follow-up, we interviewed 22 executive members (both new and old) of 12 CAMCs and six ACAP officials to gather information about what changes had occurred during the previous year (for more detail, see Baral and Stern 2010a,b). Samples of interview scripts and survey instruments are appended (Appendix 1 and 2).

We also drew upon qualitative methods such as document reviews, key informant interviews, and direct observation. All interviews with the CAMC members and ACAP officials (231 interviews) were recorded and transcribed in Nepali. English translation was done for information deemed highly relevant to the research questions. We reviewed scholarly articles, reports, official records, legal Acts, and financial documents related to ACA, and we had access to $11 \mathrm{CAMC}$ minutes books and other records at ACAP headquarters in Pokhara.

We examined the resilience of the conservation institution since its inception in 1986. Examining the life of the institution over three decades facilitated an investigation of both fast and slow variables, as distinguished in adaptive cycle theory (Walker and Abel 2002). Fast variables have time domains on the order of years, whereas slow variables may turn over on the order of decades (Light et al. 1995). The classification of system components as fast and slow variables depends on turnover time and the type of the system under investigation (Carpenter et al. 2001). In the institutional system, financial and physical capitals are typically fast variables, while human and social capitals are slow variables. Human capital includes the knowledge, skills, competencies, and attributes embodied in individuals (OECD 2001), while social capital refers to the stocks of trust, norms, social networks, and associations that enable participants to pursue shared objectives (Grootaert et al. 2004). It typically takes many years to build trusting relationships. Human skills and experience develop over similarly long periods of time. Carpenter et al. (2001) argue that system resilience is more powerfully dictated by slow variables than by fast variables. 
Resilience is difficult to measure due to its abstract, multidimensional nature; however, it can be operationalized as the ability of a system to maintain its identity (Cumming et al. 2005). In our case, the institution's primary identity is that of a functioning conservation area. We operationalized this identity by focusing on several managerial attributes, including the intentional management of the area through conservation planning undertaken in CAMC meetings and the maintenance of key conservation functions, such as a permitting system for resource harvest, restrictions on livestock grazing, controlling hunting, and maintaining the overall quality of natural resources in the area.

We built a historical profile for the region by summarizing the events that took place at the national and local levels from 1951 to 2008 and used it to depict the system's development pathway (Table 1). The focal scales were the organizational units of ACAP and CAMCs, and we linked changes at the national level to this focal level. Furthermore, we quantified structural changes in CAMCs during and following the insurgency and computed an ethnic diversity index of CAMC members using Shannon's diversity index (Krebs 1989).

\section{THE ESTABLISHMENT OF ACA}

The Forest Nationalization Act 1957 allowed the Nepali government to assume ownership of all private and communal forests (Acharya 2002). The Act eliminated private ownership of forests except for individual trees and small groves within private land, and it vested the authority to the Department of Forest as the de facto tenant and manager of forests on behalf of the people of Nepal. As a consequence, local communities were no longer permitted to manage forests under the common property regime of the past. Centralization of authority made forest resources de facto open access because the government could not enforce rules at the local level and local communities were alienated from management, which resulted in the rapid depletion of forest resources (Sherpa et al. 1986, Agrawal and Ostrom 2001). Corruption by government officials exacerbated the problem (Sherpa et al. 1986). Many older CAMC members tell of bribing government officials to get a permit to fell trees.

Nepal formally opened to the outside world in the 1960s, and the Annapurna region witnessed an influx of international visitors due to its scenic attractions, rich culture, and challenging landscapes. As the number of visitors increased, negative environmental impacts of tourism emerged: deforestation increased as forests were cleared to build hotels and meet new energy demands (Sherpa et al. 1986). An older CAMC member's statement aptly summarized the situation: "We had to walk more than an hour to collect firewood because forests surrounding the village were all gone." Tourism became a driver of change. Many scholars highlighted the problems and prospects of the Annapurna region, arguing for protected status given the fragile nature of its mountain ecosystems and its high cultural and natural value (Sherpa et al. 1986, Stevens 1997). Concurrently, local leaders also became aware of the deteriorating environment. The concept of nature conservation thus appealed to many.

The Nepali monarchy ushered in the era of modern conservation and played a crucial role in the establishment of protected areas (Bhatt 2003). In 1985, King Birendra issued a directive to protect the area by striking a balance between development and conservation, and by providing maximum benefits from tourism to local people (Sherpa et al. 1986). The King Mahendra Trust for Nature Conservation (KMTNC) - a national NGO spearheaded by the monarchy and established by legislative act in 1982 - took charge of implementing the Royal directive. A three-member study team commissioned by the Trust, which consulted with local leaders and villagers, recommended the creation of a conservation area in the region, fearing that the more restrictive national park status would cause resentment among local people. In 1986, the government approved the pilot operational plan, and the KMTNC officially launched ACAP in an 800 $\mathrm{km}^{2}$ area around Ghandruk village. The failure of government institutions, rapid environmental degradation, concern of outside scholars, support by local leaders, and interests and involvement of the Royal Family were all critical factors that led to the establishment of ACA.

\section{GOVERNANCE STRUCTURES AND PROCESSES}

Governance refers to the interactions among structures, processes, and traditions that determine how power is exercised, how decisions are made, and who is accountable for decision outcomes (Graham et al. 2003). Grassroots CAMCs have been involved in the governance of ACA since its 
Table 1. Historical profile of the Annapurna region summarizing major events that occurred at the national (N) and local (L) levels from 1951 to 2008. The four phases of the adaptive cycle are shown: exploitation $($ growth $)=r$, conservation $($ maturation $)=K$, release $($ collapse $)=\Omega$, and reorganization $=\alpha$. The phases of the adaptive cycle are applicable to the Annapurna region only, not to the national level.

\begin{tabular}{|c|c|c|c|}
\hline Year & Phase & Level & Events \\
\hline 1951 & & $\mathbf{N}$ & Modernization in Nepal began \\
\hline 1957 & $\Omega$ & $\mathbf{N}$ & $\begin{array}{l}\text { The government nationalized all forests managed by local communities and assumed the } \\
\text { absolute authority over them }\end{array}$ \\
\hline 1960 & & $\mathbf{N}$ & Nepal opened its doors to the outside world; influx of international tourists \\
\hline 1961 & & $\mathbf{N}$ & $\begin{array}{l}\text { The King took over executive power and established a political order of an absolute } \\
\text { monarchy }\end{array}$ \\
\hline 1982 & $\alpha$ & $\mathbf{N}$ & The KMTNC $\uparrow$ was established by the legislation \\
\hline 1986 & & $\mathbf{L}$ & ACAP $\ddagger$ started a pilot project in the Ghandruk village \\
\hline \multirow[t]{2}{*}{1990} & & $\mathbf{N}$ & Multiparty democracy and constitutional monarchy political order was re-established \\
\hline & $\mathbf{r}$ & & \\
\hline 1991 & & $\mathbf{N} / \mathbf{L}$ & ACAP received the Tourism for Tomorrow Award \\
\hline \multirow[t]{2}{*}{1992} & & $\mathbf{N} / \mathbf{L}$ & $\begin{array}{l}\text { ACA } \S \text { was legally gazetted as a protected area, and the KMTNC secured its } \\
\text { management authority for } 10 \text { years }\end{array}$ \\
\hline & & $\mathbf{N}$ & The Ghandruk CAMC| received the Paul Getty Wildlife Conservation Award \\
\hline 1993 & & $\mathbf{N} / \mathbf{L}$ & Forest Act 1993 gave momentum to community-based forest management \\
\hline 1994 & & $\mathbf{N} / \mathbf{L}$ & $\begin{array}{l}\text { The Ghandruk CAMC received the United Nations Environment Programme's Global } \\
500 \text { Award }\end{array}$ \\
\hline 1995 & & $\mathbf{N} / \mathbf{L}$ & Forest Regulations 1995 empowered local communities to manage forest resources \\
\hline \multirow{2}{*}{1996} & & $\mathbf{N} / \mathbf{L}$ & The Conservation Area Management Regulation and Directive were passed \\
\hline & & $\mathbf{N}$ & The Maoist insurgency began \\
\hline \multirow{4}{*}{2001} & & $\mathbf{N}$ & King Birendra was killed in the Royal Palace massacre in June \\
\hline & $\mathbf{K}$ & & \\
\hline & & $\mathbf{N}$ & The government declared a state of emergency in November \\
\hline & & $\mathbf{L}$ & $\begin{array}{l}\text { The Maoist rebels attacked the ACAP headquarters and field offices in Lwang, Sikles, } \\
\text { and Bhujung }\end{array}$ \\
\hline \multirow[t]{2}{*}{2002} & & N/L & $\begin{array}{l}\text { The government extended the management authority of the KMTNC to manage ACA } \\
\text { until } 2012\end{array}$ \\
\hline & & $\mathbf{L}$ & The Maoists destroyed the ACAP Ghandruk office \\
\hline
\end{tabular}


2003

$\Omega$

2005

2006

2008
L ACAP staff of four regional headquarters were evicted from the field bases and moved to ACAP headquarters in Pokhara

N King Gyanendra took executive power and imposed absolute monarchy

N King Gyanendra relinquished absolute power; severed ties with the KMTNC/ACAP; the KMTNC was renamed the National Trust for Nature Conservation

N The Maoists signed a comprehensive peace pact with the government declaring the official end of the insurgency

L Evicted ACAP staff returned to field bases; CAMCs reinitiated regular committee meetings

N The newly elected Constituent Assembly abolished the monarchy and declared Nepal a federal democratic republic

L $\quad$ All 56 CAMCs were reformed

$\dagger$ King Mahendra Trust for Nature Conservation

\$Annapurna Conservation Area Project

$\S$ Annapurna Conservation Area

|Conservation Area Management Committee

inception. A basic tenet is that ACA should be administered by, and not for, the community (Bunting et al. 1991). In 1992, the Nepali government gave KMTNC/ACAP the legal authority for ACA's management for 10 years. The enactment of the 1996 Conservation Area Management Regulation (CAMR) legally recognized CAMCs as local managers of ACA and secured the participation of local communities in decision making. Per the CAMR, a CAMC is formed within each village development committee (VDC). A CAMC consists of nine locally-elected members, five members nominated by ACAP staff, and the VDC chair. The tenure of CAMCs is five years. Within the jurisdictions of each CAMC, specific subgroups (e.g., tourism management, forest management, women's or youth clubs) can be formed. Most decisions are by consensus; $90 \%$ of members we interviewed reported that they never disagreed with CAMC decisions. In some cases, decisions are made by simple majority vote.

Management tasks are distributed between ACAP and the CAMCs. ACAP collects tourist fees, allocates resources to CAMCs, prepares overall management plans, complies with national legislation, and coordinates with the central government. CAMCs manage natural resources within their jurisdictions, collect revenues from harvest permits, implement conservation and development programs, mobilize local groups, and monitor all activities. The CAMR allows ACAP to delegate authority to the CAMCs, which in turn can devolve authority to subcommittees. When surveyed immediately following the Maoist insurgency in 2007, 53.2\% of CAMC members stated that their current authority was adequate, while $46.8 \%$ wished for more. About $87 \%$ of CAMC members felt that ACAP staff consult with them regularly, and all ACAP staff interviewed stated that they take input from CAMCs while making decisions.

The cross-scale interplay of organizations is necessary to address governance at various levels. This requires linking organizations horizontally across space and vertically across levels of organization (Ostrom et al. 2002, Young 2002). In ACA, horizontal linkages include networks of CAMCs, subgroups, and local NGOs. Appointing VDC chairs as de facto CAMC members also facilitates horizontal linkage. ACAP takes the lead 
in building vertical linkages with higher level actors such as the central government, national and international donors, and the regulating organizations of international conservation accords. Subcommittees and groups are at the lowest level. Above them are CAMCs, all of which are under the organization of ACAP. They are autonomous to a large degree and form a hierarchy through nested governance structures. One ACAP official gave the following reason for success, which was reflected in other interviews: "Governance of ACA has been efficient due to the involvement of actors from the village head to the state head."

\section{GROWTH AND BUILDING OF CAPITAL}

Success of the pilot project in Ghandruk led to the successive two-stage expansion of ACA from 800 to $7629 \mathrm{~km}^{2}$, which suggests that the system entered into the rapid growth ( $\mathrm{r}$ ) phase. The legal mandate for ACAP to manage ACA for 10 years secured proprietorship of communities over natural resources. This has garnered local support for conservation, as expressed by one member: "With the establishment of ACA, the government legally returned our usurped rights over natural resources. Now, we are the manager and owner of the resources of our area." ACAP implemented various integrated conservation and development projects with themes including resource conservation, alternative energy, tourism, rural development, education and extension, sustainable agriculture, cultural conservation, and women's empowerment. In the $r$ phase, the expansion and implementation of programs were facilitated by competent ACAP staff, about half of whom were from the area (Heinen and Kattel 1992, Bajracharya 2003).

Nepal's ACA experiment coincided with the international conservation movement, which advocated the integration of social and natural systems and became instrumental to the emergence of integrated conservation and development projects (MacKinnon et al. 1986, Wells et al. 1992). This made it easier for ACAP to attract international donors. The first 5-year budget was $\$ 2.5$ million, $75 \%$ of which was supplied by international sources (Stevens 1997). Subsequently, tourist fees provided a regular source for project finances. The number of tourists rapidly increased from 25,000 in 1984 to a high of 75,278 in 2000 . The collection of tourist entry fees was made possible only because of Royal patronage. Tourism provided financial resources, empowered local communities, and reduced environmental impacts to some extent (Nyaupane and Thapa 2004, Baral et al. 2008).

The emphasis in ACA has been on institutional strengthening and local capacity building, and the diversity of local forms of organization has increased since inception. As of 2000, there were 75 forestry committees, 10 endangered wildlife committees, 27 tourism committees, 13 hydroelectric committees, 13 monastery committees, 18 saving and credit groups, and 290 women's groups (ACAP 2001). These committees and groups have crafted several rules regarding nature conservation, thereby increasing the diversity of the overall conservation institution. ACAP had also provided 4467 villagers with specialized training. During the same period (1986-2000), 7267 villagers participated in adult literacy classes, and 489 girls received scholarships to attend school (ACAP 2001), all of which contributed to the development of local human capital.

Trust between villagers, CAMC members, and ACAP staff also developed over the years. In 2007, about $87 \%$ of members stated that they trusted villagers in general, and villagers conferred substantial degrees of trust to CAMCs (Baral and Stern 2010b). Internal trust within CAMCs has also developed: on average, one member trusts $88.6 \%$ (between 12 and 13) of the other 14 committee members. The levels of trust between CAMCs and ACAP are summarized in Table 2. The local origin of and frequent interactions with ACAP staff has helped build trust in them among CAMC members and local people. About half $(50.5 \%)$ of the CAMC members stated that they interact with ACAP staff at least once a month, and more than two thirds $(71.1 \%)$ reported that staff understand local cultures well. CAMCs regularly organize collective actions to manage resources and implement sustainable development programs. Building trust and undertaking collective actions are closely related to investments in social capital (Pretty and Ward 2001).

After the establishment of multi-party democracy in Nepal in 1990, democratic governments embraced the broader concept of local participation in conservation, and local NGOs became prominent actors. The democratic governments passed regulations that were favorable to ACA operations. Almost all CAMC members $(97.9 \%)$ reported that 
Table 2. Summary results of the three indicators used to measure the levels of trust building between Conservation Area Management Committees and the Annapurna Conservation Area Project. Conservation Area Management Committee members rated the following statements on a 5-point scale: always $=5$, most often $=4$, neutral $=3$, rarely $=2$, never $=1$. (Source: authors' interview data; $n=190$ )

\begin{tabular}{lcccccc}
\hline \hline Statements & Always & $\begin{array}{l}\text { Most } \\
\text { often }\end{array}$ & Neutral & Rarely & Never & Mean \pm SD \\
\hline $\begin{array}{l}\text { 1. Do you trust the ACAP staff to be } \\
\text { honest with local residents }\end{array}$ & $49.5 \%$ & $22.6 \%$ & $26.3 \%$ & $1.6 \%$ & - & $4.20 \pm 0.89$ \\
$\begin{array}{l}\text { 2. Do you trust that the ACAP staff are } \\
\text { competent in their work }\end{array}$ & $55.8 \%$ & $21.1 \%$ & $20.5 \%$ & $2.6 \%$ & - & $4.30 \pm 0.88$ \\
$\begin{array}{l}\text { 3. Do you trust that ACAP is predictable } \\
\text { and keeps up its promises }\end{array}$ & $38.4 \%$ & $45.8 \%$ & $10.0 \%$ & $5.8 \%$ & - & $4.17 \pm 0.83$ \\
\hline
\end{tabular}

the Conservation Area is appropriate for their region. Members also estimated that on average, $85.3 \%$ of villagers had positive attitudes towards ACAP.

The government holds the title to non-private lands within ACA, while local communities have the management rights to those lands. The secured property rights and active local management were critical to averting a "tragedy of the commons". This is supported by the fact that $87.4 \%$ of CAMC members reported that the status of natural resources had improved over the past decade. Furthermore, the stocks of other capital (human, social, and financial) have accumulated over the years. Available capital, competent ACAP staff, secured property rights, and local support have all triggered the rapid growth of the conservation institution within ACA.

\section{CONSERVATION SUCCESS AND EFFICIENCY}

After a decade of intervention (1986-1996), many first generation problems of the region had been addressed, further reflecting the system's entrance into a relatively stable conservation $(K)$ phase. Negative impacts of tourism had been reasonably contained, and dependency on forest resources was reduced through the establishment of plantations and alternative energy programs (Bajracharya
2003). Both ACAP staff and CAMC members explained that afforestation programs were likely to be phased out soon because most barren land had already been planted. One member described his observations of changes in resource use: "In the past, there were many pastoralists who overgrazed pastures, but now there are so few that we are afraid of losing them all."

In 2007, CAMC members favorably rated all four indicators used to assess the efficiency of the conservation institution (Table 3), suggesting that considerable efficiency had been achieved. ACAP and the CAMCs had each received several international and national awards in recognition of their contributions to conservation and sustainable development. Independent evaluation by scholars also supports the claim that conservation programs are successful in ACA (Bajracharya et al. 2005, Heinen and Shrestha 2006, Baral et al. 2007). When asked to rate the success of conservation programs on a 5-point scale, $50.5 \%$ of members ranked them "highly successful" while $42.6 \%$ ranked them "successful". One member succinctly put how increasing efficiency gave ACAP an edge over potential competitors: "Many NGOs do not venture to work within ACA just because of the fear of being in the shadow of ACAP and losing the competition."

Local villagers considered the conservation institution to be legitimate. When asked in 2007 "Is 
Table 3. Summary results of the four indicators used to measure the efficiency of the conservation institution in the Annapurna Conservation Area. Conservation Area Management Committee members were asked to rate on a 5-point scale if the following things are better or worse now than they used to be 10 years ago: much better $=5$, somewhat better $=4$, no change $=3$, somewhat worse $=2$, much worse $=1$. (Source: authors' interview data; $\mathrm{n}=190$ )

\begin{tabular}{|c|c|c|c|c|c|c|}
\hline Statement & $\begin{array}{l}\text { Much } \\
\text { better }\end{array}$ & $\begin{array}{l}\text { Somewhat } \\
\text { better }\end{array}$ & No change & $\begin{array}{l}\text { Somewhat } \\
\text { worse }\end{array}$ & $\begin{array}{l}\text { Much } \\
\text { worse }\end{array}$ & Mean $\pm \mathrm{SD}$ \\
\hline $\begin{array}{l}\text { 1. People can get permits to } \\
\text { harvest natural resources easily }\end{array}$ & $59.5 \%$ & $21.6 \%$ & $13.7 \%$ & $5.3 \%$ & - & $4.35 \pm 0.91$ \\
\hline $\begin{array}{l}\text { 2. Ordinary people can influence } \\
\text { conservation and development } \\
\text { issues in the village }\end{array}$ & $44.2 \%$ & $48.4 \%$ & $7.4 \%$ & - & - & $4.37 \pm 0.62$ \\
\hline $\begin{array}{l}\text { 3. People have an adequate } \\
\text { standard of living }\end{array}$ & $35.8 \%$ & $49.5 \%$ & $13.7 \%$ & $1.1 \%$ & - & $4.20 \pm 0.71$ \\
\hline $\begin{array}{l}\text { 4. Conservation efforts are } \\
\text { effective }\end{array}$ & $31.6 \%$ & $58.9 \%$ & $6.3 \%$ & $3.2 \%$ & - & $4.19 \pm 0.69$ \\
\hline
\end{tabular}

the CAMC the right authority to manage natural resources?", $92.2 \%$ of villagers said yes. In addition, $77.3 \%$ agreed that most villagers abide by CAMC rules. About $76 \%$ of members reported that the CAMCs are highly representative of local people, and $82.6 \%$ of members believed the distribution of conservation benefits are equitable.

As reported by respondents, an increase in forest cover has led to increased populations of wildlife, which has led to more crop and livestock depredation. No compensation measures are yet in place. About $37 \%$ of villagers surveyed in 2008 stated that this is the biggest disadvantage of ACA. Also, spatial inequality in tourism, resource allocation, and development within and among CAMCs has largely remained unresolved. The failure of the institution to solve these problems may be due to increasing rigidity, which is typical of the conservation (K) phase of the adaptive cycle. Rigidity occurs when practices become so commonplace that they become hard to change. Most ACAP officials interviewed suggested that little innovation was taking place in programs during this period (the $\mathrm{K}$ phase), which suggests a pattern of rigidity. The institution also failed to act proactively to avert some expected consequences of the Maoist insurgency. ACAP staff and CAMC members stated that they perceived threats of the insurgency at a personal level but failed to devise strategies proactively at the organizational level, which may have made the conservation institution more vulnerable to this major disturbance.

\section{THE MAOIST INSURGENCY AND COLLAPSE}

A series of events that occurred at the national level from 2001 to 2006, including the Royal Palace massacre, the declaration of a state of emergency, and the coup by King Gyanendra, were instrumental in increasing the vulnerability of ACA. The Maoist's main goal was to topple the monarchy and establish a republic. The rebels began attacking ACAP and CAMC offices (Baral and Heinen 2006). In response to our question about why rebels attacked ACAP, a local Maoist leader said "ACAP was established and operated under the monarchy's leadership. The only reason we attacked it was its ties with the monarchy." Royal patronage - one of the critical factors for ACA's success - became a liability during the insurgency. ACAP and the CAMCs also failed to address some other issues, 
such as the low degree of participation by females and low caste members. In the jurisdictions of some CAMCs, low castes, who tend to be poor, did not have access to resources, and only some, typically wealthier, people benefited from tourism (Baral et al. 2008). Some respondents in these areas explained that the Maoists exploited these shortcomings to garner some local support.

The government declared a state of emergency in 2001 and deployed the Royal Nepal Army to contain the insurgency. The army then banned all group gatherings. Regular CAMC meetings nearly ceased. Security forces harassed CAMC members and arrested some on the pretext that they supported the rebels. CAMC members also felt threatened by the rebels, and programs, such as forest patrols, that required mass participation were temporarily abandoned for fear of encounters with either the army or the rebels.

At first, Maoists extorted donations from ACAP staff members. They later forcibly evicted staff from field bases that were within their strongholds. Rebels bombed ACAP headquarters at Pokhara, and destroyed four regional headquarters and four rural offices. Rebels also vandalized three CAMC offices and intimidated, coerced, and even killed local leaders who supported ACAP (Baral and Heinen 2006). Of 190 interviewed CAMC members, $17.9 \%$ stated that they were intimidated by rebels into not serving on the committee, yet no member formally resigned. Rebels killed three local conservation leaders who opposed them. Some CAMC members and villagers migrated to urban areas for security when the insurgency escalated. Of 30 surveyed CAMCs, eight reported cases of villager displacement by the insurgency. The highest number of households that abandoned one area was 38 in Ghandruk, the village of ACA's origin. CAMC members reported that there were incidents of resource plundering (poaching for meat by the rebels and cutting of trees by some locals), but not on a large scale. The lack of law and order both at the national and local levels during the peak of the insurgency took a toll on the number of visitors to ACA: entries decreased from 75,278 in 2000 to 37,901 in 2006. This translated into deficits for several years, and 70 of ACAP's 242 staff members were laid off.

We define the collapse $(\Omega)$ phase as that in which all forms of capital declined and the performance of both organizations (ACAP and CAMCs) was compromised due to the insurgency. Layoffs of staff, displacement of villagers, and slaying of local leaders decreased human capital. Calling off regular meetings and collective action prevented new social capital formation. The destruction of infrastructure decreased physical capital. ACAP and the CAMCs could not function to their potential. The collapse, however, was not complete.

When ACAP offices were displaced, many CAMCs managed to work independently. Their performance, however, varied. Based on staff assessments and field research, there were 9 "high", 12 "medium", and 9 "low" performing CAMCs during this period. High performers initiated actions independently and often accomplished their goals despite the insurgency. Medium performers were capable of working independently, but their performance depended upon ACAP inputs and the intensity of the insurgency in their area. Low performers were more dependent upon ACAP and often failed to accomplish goals in its absence (Baral and Stern 2010b). ACAP supported CAMCs from Pokhara, and local staff maintained contact with members and followed project activities informally. In some CAMCs, members gave authority to chairs and secretaries to make decisions on behalf of the committee. In others, they devolved authority to local subcommittees or groups. All this suggests the survival of the conservation institution during the insurgency (NTNC 2008). While committee meetings decreased in some cases and some members felt that illegal hunting increased, more than $80 \%$ suggested that the status of natural resources in ACA did not diminish during the insurgency (Tables 4 and 5). These findings support the claim that ACA largely maintained its identity as a functional conservation area during the insurgency.

\section{RENEWAL AND LOOKING FORWARD}

The Maoist insurgency officially ended in November 2006 following the relinquishment of absolute power by the King. The KMTNC was renamed the National Trust for Nature Conservation (NTNC) and was brought under the patronage of the Prime Minister and the ministry in charge of protected areas, which was headed by a Maoist at that time. These events helped reorganize CAMCs and ACAP, and garnered support of the former rebels. At the time of the 2007 field study, CAMCs were reinitiating regular meetings and inducting 
Table 4. Summary results of the four indicators used to measure the changes in the identity of the conservation institution. Conservation Area Management Committee members were asked if the following activities increased, decreased, or remained the same during the insurgency. The members rated each statement on a 3-point scale: increased $=3$, remained the same $=2$, decreased $=1$. (Source: authors' interview data; $\mathrm{n}=190$ )

\begin{tabular}{lllll}
\hline \hline $\begin{array}{l}\text { Attributes assessing the identity of the functional } \\
\text { conservation area }\end{array}$ & Increased & $\begin{array}{l}\text { Remained the } \\
\text { same }\end{array}$ & Decreased & Mean \pm SD \\
\hline 1. Meeting of committee members & $7.9 \%$ & $52.1 \%$ & $40.0 \%$ & $1.68 \pm 0.61$ \\
2. Collecting natural resources without a permit & $12.1 \%$ & $82.1 \%$ & $5.8 \%$ & $2.06 \pm 0.42$ \\
3. Grazing livestock in restricted areas & $6.8 \%$ & $81.1 \%$ & $12.1 \%$ & $1.93 \pm 0.43$ \\
4. Illegal hunting of wildlife & $28.9 \%$ & $35.8 \%$ & $35.3 \%$ & $1.94 \pm 0.80$ \\
\hline
\end{tabular}

new members into vacant posts. In some CAMCs, former rebels became committee members. ACAP staff members returned to field bases in September 2007, and the four regional headquarters of the southern sectors were re-established. Regarding their return to field bases, one staff member said "We received warm welcome from the villagers. I was glad to see that even the Maoists came forward to welcome us."

All 56 CAMCs were reformed in 2008 when their 5-year term expired; they will hold office until 2013. According to interviewed staff, villagers enthusiastically participated in CAMC reformation. In 2008, surveyed villagers reported that Maoists actively participated in reformation and won a key post (chair or secretary) in many CAMCs. ACAP staff and newly elected CAMC members reported that their first priority was to reform subcommittees and groups whose terms had expired. No external support was required for reorganization. The number of visitors gradually increased from 37,901 in 2006 to 68,541 in 2008, and entry fees provided much financial capital. CAMC members had an average of $6.7 \pm 3.5$ years of experience serving on the committee. Among the sampled CAMCs, $18.1 \%$ of members of past committees served new terms following the reformation. On average, each CAMC had 2.5 experienced members who could function as a source of institutional memory. Here, institutional memory refers to a collective set of facts, concepts, experiences, and skills related to nature conservation that is held by CAMC members. This institutional memory, or know-how, can grease the wheels of innovation by allowing members to think creatively rather than having to focus additional energies on learning the basics (Baral and Stern 2010a).

Some other structural changes took place during reorganization. The ethnic diversity index for the newly formed committees $(0.80 \pm 0.33)$ was significantly greater than that of previous committees $(0.63 \pm 0.36 ; \mathrm{t}=-4.29, \mathrm{p}<0.001, \mathrm{df}=$ $29)$, as was the average number of women members $(3.07 \pm 0.87$ compared to $1.93 \pm 0.91 ; t=5.46, p<$ 0.001 , df $=29$ ). Similarly, the average number of lower caste members $(1.80 \pm 1.52)$ was significantly greater than before $(1.07 \pm 0.74 ; \mathrm{t}=3.61, \mathrm{p}=0.001$, $\mathrm{df}=29$ ).

A new governance model has been proposed for ACA, which is characteristic of the renewal $(\alpha)$ phase. Members have argued for the formation of an overarching council from all 56 CAMCs to manage ACA when the current contract with ACAP expires in 2012. Many respondents feel that with less government affiliation, the local council and CAMCs may suffer less from disturbances in the future. Although this idea started in 2001, it gained momentum during the peak of the insurgency. Many CAMCs worked independently during the insurgency and gained confidence that they could manage the area (Baral and Stern 2010b). Newly 
Table 5. Perceptions of Conservation Area Management Committee members regarding the status of natural resources within the Annapurna Conservation Area over two time periods, measured on a 3-point scale: improved $=3$, remained the same $=2$, diminished $=1$. (Source: authors' interview data; $n=190$ )

\begin{tabular}{lllll}
\hline \hline Statement & Improved & $\begin{array}{l}\text { Remained } \\
\text { the same }\end{array}$ & Diminished & Mean \pm SD \\
\hline $\begin{array}{l}\text { 1. Compared to 10 years ago, the status of natural } \\
\text { resources in your area has: }\end{array}$ & $87.4 \%$ & $6.3 \%$ & $6.3 \%$ & $13.81 \pm 0.53$ \\
$\begin{array}{l}\text { 2. In the last } 5 \text { years (during the insurgency), the } \\
\text { status of natural resources in your area has: }\end{array}$ & $3.7 \%$ & $83.2 \%$ & $1.91 \pm 0.40$ \\
\hline
\end{tabular}

elected leaders who were interviewed stated that their main priority was to form the new council before 2012; ACAP staff were optimistic that it could be formed within this timeframe. Such a council would likely transform all governance arrangements within the conservation area.

\section{DISCUSSION}

Our results show that the overall conservation institution of ACA was reasonably resilient to the Maoist insurgency. The conservation institution persisted during and following the insurgency, and ACA was able to maintain its identity as a functioning conservation area. The system successfully avoided alternative undesirable states, including loss of local control, delisting from protected area status, and unsustainable resource use. The system followed a cyclical path and entered into the reorganization phase following collapse. Although the system is reorganizing along the original regime, it has developed an alternative plan to transform in the near term; thus, it has shown both adaptive and transformative resilience (Gunderson et al. 2006). Four factors appear to have been critical in building institutional resilience in ACA: flexible nested governance structures, including the devolution of responsibility to local entities; maintenance of capital stocks; retention of institutional memory; and perceptions of institutional legitimacy among constituencies.

We contend that one and a half adaptive cycles have occurred in ACA since 1960. The first incomplete cycle started at the back loop and covered the period between the nationalization of forests in the late 1950 s and the conception of a new institution marked by the local collapse of the centralized government institution in the 1980s. The nationalization of forests and subsequent resource degradation can be termed as $\Omega$ events, and the search for a new institution as an $\alpha$ event. Scholars, local leaders, and the Royal Family provided ideas and other resources, while local people contributed their memory of traditional resource management regimes, which transformed the system following collapse. This reorganization led to a complete cycle starting at the r phase and culminating at the $\alpha$ phase. Rapid growth was possible due to Royal patronage; local, national, and international support; available capital; and local participation. By mobilizing competent staff and utilizing capital, the institution became efficient in solving many problems. With the increase in efficiency, the system became more vulnerable to disturbances due to rigidity. The Maoist insurgency was a gradual $\Omega$ event that originated outside the system and brought about collapse. Reorganization has been brought about by retaining institutional memory, preventing major leakages of capital, and undergoing structural change.

Excessive subsidization from higher panarchies tends to increase dependency, which can reduce capacity to self-organize (Abel et al. 2006). There were few external subsidies to maintain ACA. It successfully mobilized internal capital to sustain itself. Tourist entry fees provided much of the financial capital required during the insurgency 
(Baral et al. 2008). One level of governance (local) remained active when the other (regional) became inactive. CAMCs supplanted ACAP responsibilities and subcommittees supplanted CAMC activities when they could not function. This played a central role in absorbing disturbance and spreading risks. The development of trust between ACAP and CAMCs facilitated coordination between the two. Capacity-building of CAMC members was crucial to developing the confidence to manage the area independently. Institutional memory of members and staff also facilitated the reformation of CAMCs. Because more experienced members held knowledge about how the overall system has typically functioned, the CAMCs could collectively focus more on response to disturbance than on learning the basics of CAMC functioning (Baral and Stern 2010a). The $\alpha$ phase may provide opportunities to transform the institution to address emerging challenges, such as crop damage and road construction. Innovation will be critical here (Gunderson and Holling 2002).

The research supports claims that system resilience depends more on slow variables than fast variables. Carpenter et al. (2001) argue that while humans tend to respond to fast variables quickly, changes in slow variables are often overlooked. In ACA, resilience seemed linked primarily to the development and maintenance of slow variables, in particular, human and social capital development, since inception.

The adaptive cycle prescribes different policies for the back loop and the fore loop. Emphasis is given to production efficiency in the fore loop, and to retention of capital in the back loop (Abel et al. 2006). Assimilating information about slow variables (social and human capitals) and implementing appropriate policies depending upon the system's phase (an emphasis on efficiency during the fore loop and flexibility during the back loop) are critical for resilience. Accordingly, complex systems can respond to a crisis by focusing on renewal and novelty or by buffering themselves against change. Both were observed in ACA.

Adaptive cycle theory predicts that systems tend to be in the late $\mathrm{K}$ phase before collapse (Holling 1987), but this was not apparent in ACA. Although there were some indicators of increasing rigidity, we cannot rule out the possibility of the system entering into the collapse immediately following the $\mathrm{r}$ or early $\mathrm{K}$ phase. The adaptive cycle suggests that changes in natural ecosystems are commonly due to internal disturbances (i.e., intrinsic cyclicity; Holling 1987). Collapse was brought about by a major external disturbance in ACA. Others have similarly found that sufficiently large external disturbances can bring about collapse at any phase (Abel et al. 2006). Our case study did not have strong evidence for the existence of the K phase. Similar exceptions of missing one or more phases have been recorded in other social-ecological systems (Walker et al. 2006).

One prescription for resilience management is to introduce small disturbances when the system enters the late $\mathrm{K}$ phase in order to prevent collapse and bring it back into the $r$ phase (Holling 2001). This could be compared to reducing the fuel load of a forest through controlled burns to limit catastrophic response to wildfire. In community-based conservation, it might involve avoiding complacency or overly centralized concentration of power or capacity by involving new people through elections or adding new objectives through proactive planning. If we do not know whether the system is in the late K phase (as in ACA), more emphasis must be given to devising strategies to navigate the back loop smoothly. It appears that "creative destruction" (collapse) is inevitable in complex adaptive systems; therefore, policies must focus on how to minimize the extent of damage from a crisis and how to foster learning and reorganizing capabilities. Strategies could involve maintaining flexibility by spreading capacity across hierarchies. In this way, if one entity is rendered inoperable during a disturbance, another might be able to perform a similar function. This study highlights the need for paying more attention to understanding and monitoring systems that are passing through the back loop (Walker et al. 2002).

There is subjectivity in applying the adaptive cycle analogy to institutions. The framework classifies ecosystem changes into four discrete phases, while the underlying processes of institutional change may overlap across phases. The adaptive cycle emerged from ecosystem science with an assumption of defined temporal and spatial boundaries. In institutions, spatial and temporal boundaries tend to be blurred because they are embedded within large, porous socioeconomic systems. Testing the validity of the adaptive cycle in any social institution is difficult due to challenges associated with generating clearly testable 
hypotheses. Nonetheless, we believe it can serve as a useful vehicle for explaining the cyclical history of community-based conservation initiatives as they weather disturbances.

While not a perfect fit, adaptive cycle theory draws attention to critical elements that appear to have contributed to the resilience of ACA and may also be important in other community-based conservation initiatives. In particular, the concepts of flexibility and rigidity within a system can be critical to understanding factors associated with resilience. Governance systems in ACA remained flexible and thus resilient throughout the insurgency and beyond by shifting roles and responsibilities between hierarchic levels of governance. This appears to have been made possible through the development of slowly developing stocks of human and social capital (inter-level trust, local capacity, institutional memory, and local legitimacy) in addition to the maintenance of minimum requirements of other capitals. We urge other researchers and practitioners to focus more strongly on human relationships and capacity and the flexibility they can create in other conservations initiatives in which local governance may be an option.

Responses to this article can be read online at: http://www.ecologyandsociety.org/vol15/iss3/art10/ responses/

\section{Acknowledgments:}

The Rufford Small Grants Foundation, UK; the Sigma Xi, USA; and the Sigma Xi - VT Chapter provided research grants. We would like to thank all the respondents for their time and alacrity. Our special thanks go to ACAP staff for their enormous help during the various phases of this research. Janardan Bastola and Namrata Baral helped in field logistics. The first author would like to thank Dr. Bruce Hull and Dr. Tom Hammett for their support in the dissertation committee. We would like to thank three anonymous reviewers for their insightful comments.

\section{LITERATURE CITED}

Abel, N., D. H. M. Cumming, and J. M. Anderies. 2006. Collapse and reorganization in socialecological systems: questions, some ideas, and policy implications. Ecology and Society 11(1):17 [online] URL: http://www.ecologyandsociety.org/voll1/ iss1/art17/.

Acharya, K. P. 2002. Twenty-four years of community forestry in Nepal. International Forestry Review 4(2):149-156.

Agrawal, A., and E. Ostrom. 2001. Collective action, property rights, and decentralization in resource use in India and Nepal. Politics and Society 29(4):485-514.

Annapurna Conservation Area Project (ACAP). 2001. Annapurna Conservation Area (ACA): proposal for extension of ACA management. Annapurna Conservation Area Project, Pokhara, Nepal.

Bajracharya, S. B. 2003. Community involvement in conservation: an assessment of impacts and implications in the Annapurna Conservation Area, Nepal. Dissertation. Institute of Geography, University of Edinburgh, Edinburgh, UK.

Bajracharya, S. B., P. A. Furley, and A. C. Netwon. 2005. Effectiveness of community involvement in delivering conservation benefits to the Annapurna Conservation Area, Nepal. Environmental Conservation 32(2):1-9.

Baral, N., and J. T. Heinen. 2006. The Maoist People's War and conservation in Nepal. Politics and the Life Sciences 24(1-2):1-11.

Baral, N., and M. J. Stern. 2010a. Capital stocks and organizational resilience in the Annapurna Conservation Area, Nepal. Society and Natural Resources, in press.

Baral, N., and M. J. Stern. 2010b. Looking back and looking ahead: local empowerment and governance in the Annapurna Conservation Area, Nepal. Environmental Conservation 37:54-63. doi:10.1017/S0376892909990269.

Baral, N., M. J. Stern, and R. Bhattarai. 2008. Contingent valuation of ecotourism in Annapurna Conservation Area, Nepal: implications for sustainable park finance and local development. Ecological Economics 66:218-227. 
Baral, N., M. J. Stern, and J. T. Heinen. 2007. Integrated conservation and development project life cycles in the Annapurna Conservation Area, Nepal: Is development overpowering conservation? Biodiversity and Conservation 16:2903-2917.

Beier, C. M., A. L. Lovecraft, and F. S. Chapin. 2009. Growth and collapse of a resource system: an adaptive cycle of change in public lands governance and forest management in Alaska. Ecology and Society 14(2):5. [online] URL: http://www.ecology andsociety.org/vol14/iss2/art5/.

Berkes, F. 2004. Rethinking community-based conservation. Conservation Biology 18(3):621630 .

Berkes, F., and C. Folke, editors. 1998. Linking social and ecological systems: management practices and social mechanisms for building resilience. Cambridge University Press, Cambridge, UK.

Bhatt, N. 2003. Kings as wardens and wardens as kings: post-Rana ties between Nepali Royalty and national park staff. Conservation and Society 1 (2):247-268.

Bunting, B. W., M. N. Sherpa, and M. Wright. 1991. Annapurna Conservation Area: Nepal's new approach to protected area management. Pages 160-172 in P. C. West and S. R. Brechin, editors. Resident peoples and national parks: social dilemmas and strategies in international conservation. The University of Arizona Press, Tucson, Arizona, USA.

Carpenter, S., B. Walker, J. M. Anderies, and N. Abel. 2001. From metaphor to measurement: resilience of what to what? Ecosystems 4:765-781.

Cumming, G.S., G. Barnes, S. Perz, M. Schmink, K. E. Sieving, J. Southworth, M. Binford, R. D. Holt, C. Stickler, and T. V. Holt. 2005. An exploratory framework for the empirical measurement of resilience. Ecosystems 8:975-987.

Folke, C., and L. Gunderson. 2006. Facing global change through social-ecological research. Ecology and Society 11(2):43 [online] URL: http://www.eco logyandsociety.org/vol11/iss2/art43/.

Ghimire, K. B., and M. Pimbert, editors. 1997. Social change and conservation: environmental politics and impacts of national parks and protected areas. Earthscan Publications, USA.

Graham, J., B. Amos, and T. Plumptre. 2003. Governance principles for protected areas in the 21 st century. Paper prepared for the Vth World Park Congress, Durban, South Africa. Institute of Governance, Ottawa, Ontario, Canada. [online] URL: http://www.iog.ca/publications/PA governance. pdf.

Grootaert, C., D. Narayan, V. N. Jones, and M. Woolcock, editors. 2004. Measuring social capital: an integrated questionnaire. The World Bank. Washington, D.C., USA.

Gunderson, L. H., C. Folke, and M. Janssen. 2006. Generating and fostering novelty. Ecology and Society 11(1):50. [online] URL: http://www.ec ologyandsociety.org/vol11/iss1/art50/.

Gunderson, L. H., and C. S. Holling, editors. 2002. Panarchy: understanding transformations in human and natural systems. Island Press, Washington, D.C., USA.

Heinen, J. T., and B. Kattel. 1992. Parks, people, and conservation: a review of management issues in Nepal's protected areas. Population and Environment 14(1):49-84.

Heinen, J. T., and J. N. Mehta. 1999. Conceptual and legal issues in the designation and management of conservation areas in Nepal. Environmental Conservation 26(1):21-29.

Heinen, J. T., and S. K. Shrestha. 2006. Evolving policies for conservation: an historical profile of the protected area system in Nepal. Environmental Planning and Management 49(1):41-58.

Holling, C. S. 1987. Simplifying the complex: the paradigms of ecological function and structure. European Journal of Operational Research $\mathbf{3 0}$ (2):139-146.

Holling, C. S. 2001. Understanding the complexity of economic, ecological, and social systems. Ecosystems 4:390-405.

Krebs, C. 1989. Ecological methodology. Harper Collins, New York, USA.

Levin, S. 1999. Fragile dominion: complexity and the commons. Basic Books, USA. 
Light, S. S., L. H. Gunderson, and C. S. Holling. 1995. The Everglades: evolution of management in a turbulent ecosystem. Pages 103-168 in L. H. Gunderson, C. S. Holling, and S. S. Light, editors. Barriers and bridges to the renewal of ecosystems and institutions. Columbia University Press, New York, New York, USA.

MacKinnon, J., K. MacKinnnon, G. Child, and J. Thorsell. 1986. Managing protected areas in the tropics. IUCN, Gland, Switzerland.

Madzwamuse, M., and C. Fabricius. 2004. Local ecological knowledge and the Basarwa in the Okavango Delta: the case of Xaxaba, Ngamiland District. Pages 160-173 in C. Fabricius and E. Koch, editors. Rights, resources and rural development: community-based natural resource management in southern Africa. Earthscan Publications, London, UK.

McShane, T. O., and M. P. Wells, editors. 2004. Getting biodiversity projects to work: towards more effective conservation and development. Columbia University Press, New York, new York, USA.

National Trust for Nature Conservation (NTNC). 2008. Retrospective report 2002/03 to 2006/07. National Trust for Nature Conservation/ Annapurna Conservation Area Project, Pokhara, Nepal.

Nyaupane, G. P., and B. Thapa. 2004. Evaluation of ecotourism: a comparative assessment in the Annapurna Conservation Area Project, Nepal. Journal of Ecotourism 3(1):20-45.

Organization for Economic Cooperation and Development (OECD). 2001. The well-being of nations: the role of human and social capital. Organization for Economic Cooperation and Development, Paris, France.

Ostrom, E. 1990. Governing the commons: the evolution of institutions for collective action. Cambridge University Press, Cambridge, UK.

Ostrom, E., T. Dietz, N. Dolsak, P. C. Stern, S. Stonich, and E. U. Weber, editors. 2002. The drama of the commons. National Academy Press, Washington D.C., USA.

Pretty, J., and H. Ward. 2001. Social capital and the environment. World Development 29(2):209227.
Sherpa, M. N., B. Coburn, and C. P. Gurung. 1986. Annapurna Conservation Area, Nepal: operation plan. King Mahendra Trust for Nature Conservation and World Wildlife Fund, Kathmandu, Nepal.

Stevens, S. 1997. Annapurna Conservation Area: empowerment, conservation, and development in Nepal. Pages 237-261 in S. Stevens, editor. Conservation through cultural survival: indigenous peoples and protected areas. Island Press, Washington, D.C., USA.

Terborgh, J., C. vanSchaik, L. Davenport, and M. Rao, editors. 2002. Making parks work: strategies for preserving tropical nature. Island Press, Washington, D.C., USA.

Walker, B., and N. Abel. 2002. Resilient rangelands: adaptation in complex systems. Pages 293-313 in L. H. Gunderson and C. S. Holling, editors. Panarchy: understanding transformations in human and natural systems. Island Press, Washington, D.C., USA.

Walker, B., S. Carpenter, J. Anderies, N. Abel, G. Cumming, M. Janssen, L. Lebel, J. Norberg, G. D. Peterson, and R. Pritchard. 2002. Resilience management in social-ecological systems: a working hypothesis for a participatory approach. Ecology and Society 6(1):14 [online] URL: http://w ww.consecol.org/vol6/iss1/art14.

Walker, B. H., L. H. Gunderson, A. P. Kinzig, C. Folke, S. R. Carpenter, and L. Schultz. 2006. A handful of heuristics and some propositions for understanding resilience in social-ecological systems. Ecology and Society 11(1):13 [online] URL: http://www.ecologyandsociety.org/vol11/iss1/ $\underline{\operatorname{art13}}$.

Wells, M., K. Brandon, and L. Hannah. 1992. People and parks: linking protected area management with local communities. The World Bank, Washington, D.C., USA.

West, P. C., and S. R. Brechin, editors. 1991. Resident peoples and national parks: social dilemmas and strategies in international conservation. The University of Arizona Press, Tuscon, AZ, USA.

Western, D., R. M. Wright, and S. C. Strum, editors. 1994. Natural connections: perspectives in community-based conservation. Island Press, Washington D.C., USA. 
World Resources Institute (WRI) in collaboration with United Nations Development Programme, United Nations Environment Programme and World Bank. 2008. World resources 2008: roots of resilience - growing the wealth of the poor. World Resources Institute, Washington, D.C., USA.

Young, O. 2002. The institutional dimensions of environmental change: fit, interplay and scale. The MIT Press, Cambridge, Massachusetts, USA. 
APPENDIX 1. Sample interview scripts for the CAMC members in ACA, 2007

Name of the committee: Respondent code \#:

Time interview initiated: Date:

Greetings! My name is and I am conducting this research for my Ph.D. degree. I am here conducting interviews to better understand how conservation works in Annapurna. With your permission, I'd like to interview you. Every committee member has had an equal chance of being included in this study, and you have been randomly selected. Your responses will be completely anonymous, confidential and the findings will never discuss individual responses. They will be put together with over 300 other people I am interviewing, to get an overall picture. It will be impossible to pick you out from what you say, so please feel free to tell me what you think. Your participation in this study is voluntary. You do not have to answer any question you do not want to, and you can discontinue at any time without consequences. The results of the study will help to design better conservation projects, both here and abroad - especially those that empower local people.

I expect the interview to take about 30 minutes. Would you be willing to participate?

Benefits:

Please tell me about your role on the CAMC?

Why did you join the CAMC?

Why do you think others have joined?

Do you feel that you personally benefit in any way by being a CAMC member?

[1] yes [0] no

If 'yes,' what kinds of benefits do you get?

Do you think that by belonging to the CAMC have you acquired new skills or learned something valuable? [1] yes [0] no

What have you learned?

Are there any disadvantages? [1] yes [0] no. If 'yes,' please mention

Do you think that the benefits of being a member outweigh the costs? [1] yes [0] no

In your view, what are the advantages and disadvantages of working with the ACAP? 
Do you think that the advantages of working with the ACAP outweigh disadvantages or vice-versa? If so, how strongly?

$\begin{array}{lllll}\begin{array}{l}\text { Advantage } \\ \text { outweighs }\end{array} & \text { 5. Strongly } & \text { 3. About equal } & \begin{array}{l}\text { Disadvantage } \\ \text { outweighs }\end{array} & \text { 2. Barely }\end{array}$

4. Barely

1. Strongly

What role does the government play in nature conservation in your village?

Process:

How does the CAMC usually make decisions?

1 A chair decides and informs the members

3 The members hold a discussion and decide together
2 A chair asks the members what they think and then decides

4 The members hold a discussion, consult community members and decide together

5 Members vote and decision is made by a simple majority

Have there been instances in which you have disagreed with the CAMC's decisions?

[1] yes [0] no

What do you do in those cases?

How often have they happened?

Do you feel that the ACAP consult the CAMC as often as it should? [1] yes [0] no

If 'no,' should it consult more? [1] yes [0] no

Attitudes:

I'd like to read you a series of statements and would like to know whether you agree or disagree with each statement. You can tell me you agree, strongly agree, disagree or strongly disagree. You can also tell me you have no opinion. 
The concept of conservation area is appropriate in this place.
Appropriate
5. Strongly agree
3. I don't know
Inappropriate
2. Disagree
4. Agree
1. Strongly disagree

Why or why not?

I regard the conservation program in my village as successful.
Successful
5. Strongly agree
3. I don't know
Unsuccessful
2. Disagree
4. Agree
1. Strongly disagree

What do you mean by successful?

The ACAP has been crucial for proper functioning of the CAMC.

\begin{tabular}{|c|c|c|c|c|}
\hline Important & 5. Very important & 3. I don't know & Unimportant & 2. Unimportant \\
\hline
\end{tabular}

In what ways it has been crucial?

What proportion of the population do you think has a positive attitude towards the ACAP?

[1] almost none [2] less than half [3] about half

[4] more than half [5] almost everyone

What is your overall assessment of the ACAP's performance?
Good
5. Very good
3. I don't know
Bad
2. Bad
4. Good
1. Very bad

Trust:

I'd like to talk with you about who do people trust and why they trust in general. Would you please tell me your opinions regarding trust.

Would you say that most people can be trusted? [1] yes [0] no

Why or why not?

What are the important criteria for you to decide whether to trust or distrust others? 
In general, do you trust CAMC members? [1] yes [0] no

If 'yes,' how many?

[5] everyone [4] more than half [3] about half

[2] less than half [1] almost none

Do you trust that the ACAP staff to be honest with local residents? Would you say you trust/distrust them entirely or only somewhat?

$\begin{array}{llll}\text { Trust } & \begin{array}{l}\text { 3. Neither trust nor } \\ \text { distrust }\end{array} & \text { Distrust } & \text { 2. Somewhat }\end{array}$
4. Somewhat
1. Entirely

Why do you trust or distrust them?

The ACAP staff are competent in their work.
Yes
5. Always
3. I don't know
No
2. Rarely
4. Most often
1. Never

ACAP is predictable and keep up its promises.
Yes
5. Always
3. I don't know
No
2. Rarely
4. Most often
1. Never

Relationships:

Do you feel that the relationship between local residents and committee members has changed over time? How so? Please give specific events.

Has the insurgency had any impacts on the relationship? [1] yes [0] no

If 'yes,' please mention the impacts.

To your knowledge, have local people protested against any decisions the committee has made in the past?

Yes

5. Always

3. I don't know

No

2. Sometimes

4. Often

1. Never 
How many instances? \#.

Overall, how many household participate in the committee's activities?
Good
5. All households
3. About half
Bad
2. About one fourth

4. About two third

1. Almost none

How often do you formally and informally interact with ACAP staff? (Record actual response as well.)

6 More than once a month

3 Once in every 3 months
5 Once a month

2 Once in every 6 months
4 Once in every 2 months

1 Once in a year

How do you rank the ACAP staff's understanding of your culture and local situation?
Understand
5. Very well
3. To some extent
No
2. A little
4. Well
1. Not at all

History:

How long have you been on the committee? years.

To your knowledge, have there been conflicts between the government and local people in the past? [1] yes [0] no. If 'yes,' please mention the events

\section{Empowerment:}

Have you received any training from the ACAP that has been helpful to run the office?

[1] yes [0] no. If 'yes,' please mention

How much power do you have to influence the decision making processes in the CAMC?

[1] none [2] very little

[3] some [4] a lot

Do you think you should have more? [1] yes [0] no

Do you think local people have the power to influence the CAMC's decision?

[1] yes [0] no. If 'yes,' how?

Do some people have more power than others? Who? 
How satisfied are you with the functioning of the CAMC?

Yes

5. Extremely satisfied

3. Don't know

No

2. Unsatisfied

4. Satisfied

1. Extremely unsatisfied

How often do other CAMC members listen to your suggestions?
Listen
5. Always
3. Sometimes
Don't care
2. A few times
4. Most times
1. Not at all

How many members listen to your suggestions? \#.

Norms:

What proportion of your friends do you feel are in agreement with what the CAMC is doing? [1] almost none [2] less than half [3] about half

[4] more than half [5] almost everyone

Has that changed over time? [1] yes [0] no

Do some people benefit more from the conservation program than others? [1] yes [0] no

Who benefits most?

Are they on the CAMCs? [1] yes [0] no

What proportion of people who live here trust the ACAP?

Why do you think other people trust or distrust the ACAP?

How important is it for you to be on the committee?
Important
5. Very important
3. Neither-nor
Unimportant
2. Quite unimportant
4. Quite important
1. Very unimportant

Motivations:

Were you on the CAMC before? [1] yes [0] no.

If 'yes,' how many times 
Would you like to serve on the CAMC for another term?

Yes

5. Most likely

3. Undecided

No

2. Unlikely

4. Likely

1. Very unlikely

Why or why not?

Social relations:

Has anybody suggested you to file a candidacy for the membership? [1] yes [0] no If 'yes,' who?

Apart from you, is anybody from your household a member of any committee, group or organization? [1] yes [0] no. If 'yes,' how many

If the CAMC needs any help to complete a project, whom do you contact to get the help? Please mention all persons, organizations, agencies, etc.

How many people within the CAMC have acquired the capability and qualities to be effective leaders?

(Please record the actual number

[1] none (0) [2] few (1-3) [3] some (4-6)

[4] many (> 6) [5] all

Do the leaders tend to come from a few groups or families that are always the same, or do the leaders represent a wider circle among the community?

[1] from few groups [2] from various groups within the community

[3] from almost all the groups within the community

Legitimacy:

Please say whether you agree or disagree with the statement. The CAMC has the right to make decisions that all villagers have to abide by, whether or not they agree with them.
Yes
5. Strongly agree
3. Neutral
No
2. Disagree
4. Agree
1. Strongly disagree

Has your perception about the utility of the CAMC changed? Past three years vs. before the insurgency.

Institutional arrangements:

How long has your CAMC been in the place? years

How well do you think various ethnic groups are represented in your CAMC?

[4] highly representative [3] somewhat representative

[2] slightly representative [1] not representative at all

What is the mission of your CAMC? 
Overall, how effective is the committee's leadership?

[3] very effective [2] somewhat effective [1] not effective at all

What do you consider to be the biggest challenges the ACA is facing today?

Resource status:

Would you please tell me whether the status of natural resources has improved, remained the same or worsened during the following time periods?

Statement

Improved (3) Remained the Worsened (1)

Compared to 10 years ago, the status of natural resources in your area

has:

In the last five years (after the insurgency), the status of natural resources

in your area has:

Environmental values:

Do you think protecting this park is important? [1] yes [0] no. Why?

There could be many reasons that motivate you to conserve this area. Would you please tell me how important to you is each of the following reasons?

Reason

Very important (3)

Important (2)

Not important (1)

To meet my natural resource needs

To protect animals and plants

To help others meet their needs

To maintain ecological balance 
Institutional resilience:

In your opinion, have the following activities increased, decreased or remained the same during the insurgency?

Activity

Increased

Remained the same

Decreased

Meeting of committee members

Collecting natural resources without a permit

Grazing livestock in restricted areas

Hunting wildlife

We are going to assess the outcomes of the present management regime. Please tell me if the following things are better or worse now then they used to be 10 years ago.

$\begin{array}{lllll}\text { Statement } & \begin{array}{l}\text { Much } \\ \text { better }\end{array} & \begin{array}{l}\text { Somewhat } \\ \text { better }\end{array} & \text { No change } \begin{array}{l}\text { Somewhat } \\ \text { worse }\end{array} & \begin{array}{l}\text { Much } \\ \text { worse }\end{array}\end{array}$

People can get permits to harvest natural resources easily

Ordinary people can influence conservation and development issues in the village

People have an adequate standard of living

Conservation efforts are effective

Have you received any threat against you as a CAMC member? [1] yes [0] no

If 'yes,' why did not you resign?

Have you lost anything as a result of the insurgency?

Have you learned anything new as a result of the insurgency?

What strategies have you adopted to cope with the insurgency?

Collective action, conflict and information:

In the past year, how often did the CAMC organize collective actions?

$[0]$ never $(0)$ [1] occasionally (1-5 times)

[2] frequently (6-10 times) [3] always (> 10 times) 
Compared with other villages, is there more or less conflict in your village?

[1] more [2] the same [3] less

What are your three most important information sources about what the government is doing (such as conservation programs, development activities, agricultural subsidies, etc.)?

1 .

2.

3.

Did people migrate from your village due to the insurgency? [1] yes [0] no. If 'yes,' how many?

Can CAMCs manage the ACA on their own? [1] yes [0] no

Why or why not?

If the government decides to hand over the ACA to CAMCs, how long do you think your committee needs to take the responsibility solely?

[5] < a year [4] 1-2 years [3] 3-4 years

[2] 5-6 years $[1]>6$ years

Socio-demographic:

Please check one: [1] male [0] female Ethnicity:

What is your age? years

How many people including you live in your household?

Have you migrated to this place? [1] yes [0] no. If 'yes,' which year From where?

How much education have you had?

What is your main occupation?

What statement best describes your total annual household income (from all sources and before taxes)?

1 Less than NRs. 30,000

4 NRs. $90-120,000$
$2 \quad$ NRs. $30-60,000$

5 more than NRs. 120,000
3 NRs. $60-90,000$

Thank you very much for your cooperation.

Time interview terminated: 
APPENDIX 2. Sample questions for the local villagers in ACA, 2008

Respondent code \#: Place: Date:

Socioeconomic status: Gender: [1] Male [0] Female

Namaste! I am

and I am here to learn about nature conservation in your village. I will be doing surveys of villagers to know their opinions about the CAMC's performance and conservation programs. Your responses will be completely confidential, and the findings will never discuss individual responses. It will be impossible to pick you out from what you say, so please feel free to tell me what you think. Will you take a little while to participate in this survey?

1. How often have you participated in programs organized by the CAMC?

[3] often [2] rarely [1] never

2. Do you trust CAMC members to work on behalf of all villagers' interests?

[3] yes [2] sometimes [1] no

3. Do you trust that the CAMC members treat all villagers equally?

[3] yes [2] sometimes [1] no

4. Do you trust that the CAMC members are honest?

[3] yes [2] sometimes [1] no

5. In your opinion, is CAMC the right authority to manage natural resources?

[3] yes [2] maybe [1] no

6. Do you think most villagers abide by CAMC's rules?

[4] always [3] usually [2] rarely [1] never

7. Do you think that the decisions made by the CAMC should be obeyed?

[3] yes [2] mostly [1] no

8. How do you judge the CAMC's overall performance?

[3] good [2] fair [1] poor

9. Are there any advantages of having the CAMC in your village? [1] yes [0] no.

If 'yes', please mention:

10. Are there any disadvantages of having the CAMC in your village? [1] yes [0] no.

If 'yes', please mention:

11. Do you think the benefits of having the CAMC outweigh the disadvantages?

[3] yes, the benefits outweigh any disadvantages

[1] no, the disadvantages outweigh the benefits

[2] the benefits and disadvantages are about equal

12. How many of your friends and relatives have favorable attitudes towards CAMC?

[3] most [2] some [1] almost none 
13. How much influence do you think people like yourself can have in CAMC activities?

[3] a lot [2] some [1] not at all

14. How often have the CAMC members listened to your suggestions, concerns or problems?

[3] often [2] rarely [1] never

Now, I would like to talk with you about ACAP and its staff.

15. What do you think about ACAP's job in your village?

[3] good [2] fair [1] poor

16. Do you trust ACAP staff to work on behalf of all villagers' interests?

[3] yes [2] mostly [1] no

17. Do you trust that the ACAP staff are honest?

[3] yes [2] mostly [1] no

18. Do you feel that the ACAP brings any benefits to you or your family?

[1] yes [0] no

19. Do you feel that the ACAP brings any disadvantages to you or your family?

[1] yes [0] no

20. Do you feel that the benefits of living within the ACAP outweigh the disadvantages?

[3] yes, the benefits outweigh any disadvantages

[1] no, the disadvantages outweigh the benefits

[2] the benefits and disadvantages are about equal

21. How successful do you feel the conservation programs are in your village?

[3] very successful

[2] somewhat successful

[1] not successful

22. How do you assess the status of natural resources in your village?

Statement

a. Compared to the pre-ACAP era, the status of natural resources in your area has:

b. Compared to 10 years ago, the status of natural resources in your area has: $\begin{array}{ll}\text { Improved (3) } & \begin{array}{l}\text { Remained the } \\ \text { same (2) }\end{array} \quad \text { Worsened (1) }\end{array}$ 
c. Compared to 5 years ago (during the insurgency), the status of natural resources in your area has:

23. How active was your CAMC during the Maoist insurgency?

[3] very active [2] somewhat active [1] inactive

24. How do you assess the overall performance of your CAMC during the insurgency? [3] good [2] fair [1] poor

25. Do you feel that conservation was happening in your village during the insurgency?

[3] yes [2] somewhat [1] no

26. How important was the CAMC's role for making the conservation happen during the insurgency?

[3] very important [2] somewhat important [1] not important

27. Would it be better not to have 'conservation area' here?

[3] not at all [2] maybe in some situations [1] of course yes

28. Have you migrated to this village? [1] yes [0] no. If "yes", when?___ years ago.

29. Are you related to any CAMC members? [1] yes [0] no. If "yes", what is the relationship?

30. Socio-demographic characteristics of respondents:

Age: ___ years (please ask how old the respondent is).

Education: (please record the level of education).

Ethnicity: (please ask the respondent's full name). 